\title{
AKTIVITAS ANTIOKSIDAN KULIT BATANG LIBO (Ficus variegata Blume)
}

\author{
Dewi Noorjannah Utami, Agung Rahmadhani, Jaka Fadraersada, Rolan Rusli* \\ Laboratorium Penelitian dan Pengembangan FARMAKA TROPIS Fakultas Farmasi \\ Universitas Mulawarman, Samarinda, Kalimantan Timur \\ *email: rolan@farmasi.unmul.ac.id
}

\begin{abstract}
Libo (Ficus variegata Blume.) is one of the plants that have potential as a traditional medicine and the content of these plants can be used as an antioxidant. The aims of this research was to determine the potential of libo bark skin as a medicinal plant with examine the antioxidant activity using DPPH method. Extraction was done by using methanol subsequently fractionated by liquid-liquid fractionation method using three solvents viz nhexane, ethyl acetate and n-butanol. The results showed that n-butanol fraction has the highest antioxidant activity followed by a fraction of ethyl acetate, methanol extract and fraction of $\mathrm{n}$-hexane, with $\mathrm{IC}_{50}$ values respectively were $12.05 \mathrm{ppm}, 14.10 \mathrm{ppm}, 26.70$ ppm, and $47.54 \mathrm{ppm}$. The secondary metabolites of libo bark are alkaloids, phenols and tannins.
\end{abstract}

Keywords: Libo bark skin, antioxidant, DPPH

\begin{abstract}
ABSTRAK
Tumbuhan libo merupakan salah satu tumbuhan yang memiliki potensi sebagai obat tradisional dan kandungan dari tumbuhan ini salah satunya dapat digunakan sebagai antioksidan. Tujuan dari penelitian ini adalah untuk mengetahui potensi dari kulit batang libo sebagai tanaman obat dengan melakukan pengujian aktivitas antioksidan menggunakan metode DPPH. Ekstraksi dilakukan dengan menggunakan pelarut metanol yang selanjutnya difraksinasi dengan metode fraksinasi cair-cair dengan menggunakan tiga pelarut yaitu n-heksan, etil asetat dan n-butanol. Hasil penelitian menunjukkan fraksi nbutanol memiliki aktivitas antioksidan tertinggi diikuti oleh fraksi etil asetat, ekstrak metanol dan fraksi n-heksan, dengan nilai $\mathrm{IC}_{50}$ berturut-turut adalah sebesar 12,05 ppm, 14,10 ppm, 26,70 ppm, dan 47,54 ppm. Kandungan metabolit sekunder kulit batang libo adalah alkaloid, fenol dan tannin.
\end{abstract}

Kata kunci : kulit batang libo, antioksidan, DPPH

\section{PENDAHULUAN}

Antioksidan merupakan substansi yang penting untuk melindungi tubuh dari bahaya radikal bebas. Radikal bebas merupakan suatu senyawa atom atau molekul yang mengandung satu atau lebih elektron yang tidak berpasangan. Adanya elektron yang tidak berpasangan menyebabkan senyawa tersebut sangat reaktif mencari pasangan, dengan cara mengikat elektron molekul yang berada disekitarnya, yang dapat mengakibatkan terbentuknya senyawa radikal baru. Oleh karena itu pembentukan radikal bebas harus dihalangi atau dihambat dengan suatu senyawa yaitu antioksidan [1]. 
Salah satu tumbuhan yang menarik untuk di teliti sebagai sumber komponen aktif antioksidan adalah tumbuhan libo. Tumbuhan libo merupakan tumbuhan yang tumbuh di hutan secara liar. Penelitian mengenai aktivitas antioksidan dari tumbuhan libo pernah dilakukan, pada bagian buah dan daun dengan nilai IC 50 terbaik adalah 28,44 ppm [2], sementara penelitian mengenai aktivitas antioksidan kulit batang libo belum pernah dilaporkan. Diduga selain buah dan daun libo, kulit batang libo juga memiliki potensi aktivitas yang tidak jauh berbeda, mengingat buah libo yang tumbuh pada batang dan ranting sehingga memungkinkan kulit batang libo juga mengandung metabolit sekunder yang sama seperti buah yang berpotensi sebagai antioksidan. Sehubungan dengan itu maka dilakukan penelitian mengenai potensi aktivitas antioksidan kulit batang libo sehingga dapat melengkapi data ilmiah tumbuhan libo.

\title{
METODE PENELITIAN
}

\section{Bahan}

Bahan yang diteliti adalah kulit batang libo diperoleh dari lingkungan Universitas Mulawarman. Bahan-bahan kimia yang digunakan adalah n-heksan, etil asetat, n-butanol, metanol pro analisis, pereaksi meyer, pereaksi dragendroff, kloroform, serbuk Magnesium, asam klorida, asam asetat anhidrat, aquades, $\mathrm{FeCl}_{3}, \mathrm{H}_{2} \mathrm{SO}_{4}$ dan DPPH (Sigma Aldrich).

\begin{abstract}
Alat
Alat-alat yang digunakan adalah seperangkat alat maserasi, seperangkat alat gelas yang biasa digunakan di laboratorium, rotary evaporator (büchi rotavapor R-200), spektrofotometri UV-Vis, water bath $\left(\right.$ WiseBath $\left.^{\circledR}\right)$, vortex dan timbangan analitik.
\end{abstract}

\section{Prosedur}

Sampel kulit batang yang telah dikumpulkan, dibersihkan dari pengotor, dipotong kecil-kecil lalu dikeringkan dengan menggunakan oven. Sampel yang telah kering lalu dimaserasi dengan menggunakan n-heksan selama \pm 3 hari, lalu dimaserasi kembali dengan metanol, dipekatkan dengan rotary evaporator dan dikeringkan pada water bath.

Selanjutnya dilakukan uji metabolit sekunder pada ekstrak metanol kulit batang libo yang meliputi uji alkaloid, uji fenol, uji steroid, uji saponin, uji flavonoid dan uji tanin. Identifikasi senyawa alkaloid menggunakan pereaksi Dragendroff dan Meyer. Identifikasi senyawa fenol dengan menggunakan larutan besi (III) klorida. Identifikasi senyawa steroid dengan menggunakan asam asetat anhidrat dan asam sulfat pekat. Identifikasi senyawa saponin dilakukan dengan penambahan aquades lalu dikocok kuat dan ditambahkan HCl. Identifikasi senyawa flavonoid dengan menggunakan metanol, serbuk $\mathrm{Mg}$ dan $\mathrm{HCl}$. Identifikasi senyawa tanin dengan menggunakan gelatin dan $\mathrm{FeCl}_{3}$ [3].

Ekstrak metanol kulit batng libo kemudian difraksinasi menggunakan pelarut $n$ heksan, etil asetat dan $n$-butanol, yang selanjutnya digunakan untuk pengujian antioksidan. Diambil masing-masing $2 \mathrm{~mL}$ larutan ekstrak dan fraksi kemudian ditambahkan dengan 2 mL larutan DPPH 40 ppm. Dibuat variasi konsentrasi sampel yaitu 5 ppm, 10 ppm, 15 ppm, 20 ppm dan 25 ppm. Selanjutnya divortex dan diinkubasi selama 30 menit pada suhu ruang dan terhindar dari cahaya. Kemudian diukur absorbansinya pada panjang gelombang maksimumnya. Kekuatan inhibisinya dihitung menggunakan rumus.

$$
\% \text { Inhibisi }=\frac{\text { Abs. Blanko }- \text { Abs. Sampel }}{\text { Abs. Blanko }} \times 100 \%
$$




\section{HASIL DAN PEMBAHASAN}

\section{Metabolit Sekunder Ekstrak Metanol Kulit Batang Libo}

Metabolit sekunder adalah senyawa metabolit yang tidak esensial bagi pertumbuhan organisme dan ditemukan dalam bentuk berbeda-beda antara spesies yang satu dan lainnya. Fungsi metabolit sekunder adalah untuk mempertahankan diri dari kondisi lingkungan yang kurang menguntungkan, misalnya untuk mengatasi hama dan penyakit, menarik polinator, dan sebagai molekul sinyal [4].

Berdasarkan hasil metabolit sekunder pada tabel 1 menunjukkan bahwa ekstrak metanol kulit batang libo memiliki kandungan senyawa metabolit sekunder berupa alkaloid, tanin dan fenol.

Tabel 1. Hasil uji metabolit sekunder kulit batang libo

\begin{tabular}{ccc}
\hline No & Uji & Hasil \\
\hline 1 & Steroid & - \\
2 & Fenol & + \\
3 & Flavanoid & - \\
4 & Tanin & + \\
5 & Saponin & - \\
6 & Alkaloid & + \\
\hline Keterangan: (-) Tidak terdeteksi (+) Senyawa Terdeteksi
\end{tabular}

\section{Uji aktivitas antioksidan}

Uji aktivitas antioksidan kulit batang libo dilakukan dengan metode DPPH, metode ini merupakan metode yang sederhana dan yang paling umum digunakan untuk skrinning awal pengujian aktivitas antioksidan karena cepat dan sampel yang digunakan sedikit. Uji aktivitas antioksidan dilakukan pada ekstrak metanol, fraksi n-heksana, fraksi etil asetat dan fraksi n-butanol. Kemampuan penangkapan radikal DPPH oleh suatu antioksidan dinyatakan dengan nilai persen penangkapan radikal. Nilai yang semakin tinggi menunjukkan bahwa sampel yang digunakan berpotensi sebagai antioksidan [5].

Besarnya aktivitas antioksidan ditandai dengan nilai IC $_{50}$ yaitu besarnya konsentrasi senyawa uji yang dapat menangkap radikal sebesar $50 \%$. Suatu senyawa dikatakan memiliki aktivitas antioksidan sangat kuat apabila nilai $\mathrm{IC}_{50}$ kurang dari $50 \mathrm{ppm}$, kuat apabila nilai $\mathrm{IC}_{50}$ antara 50-100 ppm, sedang apabila nilai $\mathrm{IC}_{50}$ berkisar antara 100-150 ppm, dan lemah apabila nilai $\mathrm{IC}_{50}$ berkisar antara $150-200$ ppm [6]. Nilai $\mathrm{IC}_{50}$ kulit batang libo pada ekstrak metanol, fraksi n-heksan, fraksi etil asetat dan fraksi n-butanol menunjukkan kulit batang libo memiliki aktivitas antioksidan yang sangat kuat, yang ditunjukkan pada tabel 2.

Tabel 2. Hasil uji aktivitas antioksidan kulit batang libo

\begin{tabular}{lll}
\hline No & Sampel & IC $_{50}$ \\
\hline 1 & Ekstrak metanol & $26,704 \mathrm{ppm}$ \\
2 & Fraksi n-heksana & $47,540 \mathrm{ppm}$ \\
3 & Fraksi etil asetat & $14,103 \mathrm{ppm}$ \\
4 & Fraksi n-butanol & $12,058 \mathrm{ppm}$ \\
\hline
\end{tabular}


Berdasarkan nilai $\mathrm{IC}_{50}$ aktivitas antioksidan yang paling kuat adalah fraksi n-butanol dengan nilai $\mathrm{IC}_{50}$ lebih kecil, sedangkan fraksi n-heksana memiliki nilai $\mathrm{IC}_{50}$ yang lebih besar yang menunjukkan bahwa senyawa aktif pada fraksi n-heksan memiliki kemampuan mendonorkan elektronnya lebih rendah dibandingkan fraksi n-butanol, fraksi etil asetat dan ekstrak metanol. Hal ini diduga karena kandungan senyawa fenol yang berperan sebagai antioksidan paling banyak terdapat pada fraksi n-butanol, fraksi etil asetat dan ekstrak metanol.

\section{KESIMPULAN}

Berdasarkan hasil yang diperoleh dapat disimpulkan bahwa, ekstrak metanol kulit batang libo mengandung metabolit sekunder alkaloid, fenol dan tanin. Kulit batang libo memiliki aktivitas antioksidan yang sangat kuat dengan nilai $\mathrm{IC}_{50}$ terbaik pada fraksi nbutanol diikuti oleh fraksi etil asetat, ekstrak metanol dan fraksi n-heksan, dengan nilai $\mathrm{IC}_{50}$ berturut-turut adalah sebesar $12,05 \mathrm{ppm}, 14,10 \mathrm{ppm}, 26,70 \mathrm{ppm}$, dan 47,54 ppm.

\section{DAFTAR PUSTAKA}

1. Selawa W., Revolta M. dan Runtuwene J. 2013. Kandungan flavonoid dan kapasitas Antioksidan Total Ekstrak Etanol daun Binahong (Anredera cordifolia). Jurnal Ilmiah Farmasi. 2. (1). 18-22.

2. Titin, Ratna. 2013. Aktivitas Antioksidan Ekstrak Buah Libo (Ficus Variegeta BL). Skripsi. Fakultas Farmasi Universitas Mulawarman. Samarinda.

3. Harborne,J. 1987. Metode Fitokimia. Institut Teknologi Bandung: Bandung.

4. Murniasih, Tutik. 2003. Metabolit Sekunder dari Spons sebagai Bahan Obat-obatan. Oseana. 28. (3). 27-33.

5. Ridwana, G. 2008. Perbandingan Pengukuran Aktivitas Antioksidan dari Ekstrak Etanol Minyak Atsiri Lempuyung Gajah. Skripsi. FMIPA IPB. Bogor.

6. Molyneux, P. 2004. The Use of Stable Free Radical Diphenylpicrylhydrazyl (DPPH) for Estimating Antioxidant Activity. Journal of Science Technology. 26. (2). 211-219. 